\title{
A Corpus Based Study of the Relationship among the Iranian EFL Students' Gender, Language Proficiency, and Cross-cultural Knowledge of Apologizing and Requesting
}

\author{
Javad Bijari \\ Department of English, Hamadan Branch, Islamic Azad University, Science and Research Campus, Hamadan, Iran \\ Ali Gholami Mehrdad \\ Department of English, Hamadan Branch, Islamic Azad University, Science and Research Campus, Hamadan, Iran \\ Lotfollah Karimi \\ Department of English, Hamadan Branch, Islamic Azad University, Science and Research Campus, Hamadan, Iran
}

\begin{abstract}
One of the issues in communicative language teaching (CLT) domain is pragmatic knowledge. One of the issues that has gained significance in pragmatic studies is the relationship among pragmatic knowledge, gender, and language proficiency. A few studies have investigated the effect of gender on pragmatics knowledge and the relationship between language proficiency and pragmatic knowledge; on the other hand, few of these studies have been corpus based. In this study, the relationship among the Iranian EFL students' gender, language proficiency, and comprehension of speech acts (apologizing and requesting) were examined. Then the findings were compared with the international corpus collections of the speech acts. To that end, 30 male and 30 female EFL students from Islamic Azad university of Hamadan were selected through quota sampling. Two kinds of tests, IELTS test and Discourse Completion Task (DCT) test, were administered to measure the students' language proficiency and speech acts knowledge. The results of data analysis showed that in pragmatics test, the female students outperformed the male students and in language proficiency test male students outperformed female ones. Therefore, the results of this study implied that gender affects the students' pragmatic knowledge and there is no relationship between pragmatic knowledge and language proficiency knowledge.
\end{abstract}

Index Terms-communicative competence, pragmatic knowledge, speech acts, corpus

\section{INTRODUCTION}

Communicative competence has been with us for nearly three decades (Kasper \& Rose, 2001). The term "communicative competence" was coined by Hymes (1972). Hymes (1972) believes that the language users must not only be able to apply and use grammatical rules, but also to know how to use them appropriately.

One of the manifestations of communicative competence is pragmatic competence and the ability to utilize appropriately different speech acts in communications. Studies of cross-cultural pragmatics report that the way speech acts are realized varies across languages. This variation can sometimes cause misunderstandings, or what Thomas(1983) called pragmatic failure.

According to Thomas (1983) lack of pragmatic awareness is most evident among EFL learners while communicating with people from other cultures. Teachers in EFL classrooms are partly responsible for the lack of pragmatic knowledge among learners. EFL teachers mostly concentrate on the grammar and vocabulary (linguistic competence) and they do not pay sufficient attention to the pragmatic or sociolinguistic dimension of language.

Eslami-Rasekh (2008) believes the communication of EFL learners with native speakers (NSs) may bring about pragmatic failure due to the lack of pragmatic knowledge of the sociocultural norms of the target community. As such, pragmatic competence should be acquired in order to lessen pragmatic failure or communication breakdowns between native speakers (NSs) and non-native speakers (NNSs).

Most of the researchers (e.g. Bardovi-Harlig, 2003; Kasper, 2001; Kondo, 2008; Tateyama \& Kasper, 2008) believe that pragmatic knowledge is teachable, but their methods for teaching pragmatics is different. For example, BardoviHarlig (2003) argues that the classroom is a place where pragmatic instruction can occur. On the other hand, Koike and Pearson (2005) found out that the rate of acquisition of pragmatic competence was faster when English-speaking learners of Spanish received explicit instruction and feedback. 
One of the issues in pragmatics teaching is the effect of students' gender and language proficiency on their pragmatic knowledge. Unfortunately, of the researches in the pragmatic domain, a few of them have considered the relationship among the EFL students' gender, language proficiency, and cross-cultural knowledge of speech acts. Studies in this domain are scarce and few of them have been corpus based. Therefore, the purpose of this study is to inspect relationships among the students' understanding of the speech acts, their gender, and their language proficiency and compare the results based on the corpus studies of speech acts to know which group's speech act knowledge is closer to native speakers of English; the male group or the female one; the group with high language proficiency knowledge or the group with low one.

\section{BACKGROUND STUDIES}

The term "pragmatics" can be said to derive from Peirce's "pragmatism", a philosophical movement of late 19th century. Pragmatism can be said to be akin to 20th century Anglo-Saxon linguistic philosophy, from which present day pragmatics eventually evolved. According to Kitis and Milapides (1997) the term "pragmatics" is owed to Morris(1938) who distinguished the three levels of linguistic theory: Syntactic, semantics and pragmatics. Syntax studies the relations signs bear to other signs, semantics studies the relation between signs and objects, and pragmatics studies the relation between signs and their interpreters. After about thirty years elapsed, pragmatics finally made its way into modern linguistics in the late 1960s, when linguists began to explore so-called performance phenomena. To this end, they adopted ideas developed and advanced by L. Wittgenstein, G. Ryle, J.L. Austin and other eminent (ordinary or natural) language philosophers (Bublits and Norrick, 2011).

Pragmatics has been defined in various ways, one of the earliest definitions is proposed by Morris (1938) who defined pragmatics as the study of the relations of signs to interpreters. The most popular definition has been offered by Crystal who believes that pragmatics is "the study of language from the point of view of users, especially of the choices they make, the restriction they encounter in using language in social interaction and the effects their use of language has on other participants in the act of communication" (Crystal, 1997; cited in Kasper \& Rose, 2001, p. 2). A more recent definition of pragmatics has been proposed by Barron (2003), who believes pragmatics is "knowledge of the linguistic resources that are used in a given language for realizing particular meanings in context, knowledge of the aspects of speech acts and finally knowledge of the contextual use of the particular languages' linguistic resources"( p.10).

Pragmatics as an area of query within foreign language acquisition is usually named as Inter language Pragmatics. Inter language pragmatics is convinced as the "nonnative speakers' comprehension and production of speech acts, and how their L2 (second language)-related speech act knowledge is acquired” (Kasper and Dahl 1991, p. 1).

There are some empirical evidence that show native speakers and nonnative speakers have different systems of pragmatic in production and perception of language; for this reason when they want to acquire a second language they will encounter with so many problems because their inter language pragmatics (ILP) is not so good. One piece of such evidence is speech acts, such as compliments, complaining, refusals, apologizing, requesting. "speech acts are often but not always the patterned, routinized language that native and pragmatically nonnative speakers and writers in a given speech community use to perform functions such as thanking, complimenting, requesting, refusing, apologizing and complaining" (Olshtain \& Cohen 1991, p.19).

One of the issues in the domain of pragmatic knowledge is the effect of gender on pragmatics acquisition. Kerekes (1996) found that female learners are more interested in using L2 norms in expression of emotions than male learners did. In another study, however, Rintell (1984) found no gender differences in learner's perception of expression of emotions. As to directness and indirectness, Wolfson \& Manes (1980) found out that women are less direct; this is because women tend to be more agreeable; on the other hand, men tend to be more direct than women are. In another study, Holmes (1995) found out that women's speech is more polite than men's and women are more likely than men to express positive politeness and to use mitigating strategies.

Another issue in the pragmatics studies is the effect of language proficiency (LP) on pragmatic competence (PC). Takahashi (1996) found that Proficiency did not have any effect on pragmatic competence (PC). EFL learners with both low and high proficiency lied on some of the SL pragmatic aspects. Kit (2000) found that learners across several levels of proficiency are capable of perceiving differences in situational factors. Proficiency did not have the expected effect on pragmatic competence (PC). He adds the main reason may be attributed to the fact that EFL learners just learned English through what they were exposed to in the classroom; the problem was lack of access to authentic materials. In another study, Barron (2003) pointed out that increased grammatical proficiency may or may not cause a corresponding increase in pragmatic capabilities. It may allow the learner to construct or overuse a structure which is pragmatically less effective.

One of the newly developed issues in the linguistic researches is corpora. O'Keeffe et al (2007) believe a corpus is a collection of texts, written or spoken, which is stored on a computer. Corpora have been available for linguistic research from the 1960s. Since the early days of corpus linguistics, there has been an interest in using corpora as a means of exploring functional and contextual aspects of language use. Pragmatics is concerned with meaning in context. Because speakers can mean more than they say, pragmatics is "the art of the analysis of the unsaid" (Mey, 1991; cited in Rühlemann, 2011, p. 629). 
Due to the massive dependence of pragmatic phenomena on context, corpora, as a relatively decontextualized environment, have long been seen by some researchers as unfit for use in pragmatic research. Nonetheless, some corpus-based analyses of pragmatic phenomena have been in recent years.

In a study of speech acts in corpora, Taavitsainen and Jucker (2007) looked at the relevant speech-act verbs in a large mixed corpus. They started with specific patterns of linguistic expressions and test their precision and recall in large corpora (e.g. patterns often used as compliments or explicit performatives, containing speech-act verbs of promising). These, and similar studies, produce instructive and remarkable results, given the complexity of the speech acts involved (e.g. compliments), the size of the corpora tested (e.g. the BNC) and the standards of qualitative and quantitative assessment. Lorenzo-Dus (2001) examined a corpus of over 1000 tokens of compliment responses in British English and Peninsular Spanish in terms of cross-cultural and gender differences. The analysis of the outcome revealed crosscultural and gender differences.

\section{METHODS}

\section{A. Participants}

The sample participating in this study consisted of 60 individuals (30 males and 30 females) who were all native speakers of Persian and their age ranged from 18 to 32. They were studying English as a foreign language in Islamic Azad University of Hamadan. They were all senior undergraduate and graduate students majoring in Teaching English as a Foreign Language (TEFL).

\section{B. Instruments}

In order to collect the data, two data collection instruments were utilized. The first one was IELTS test. It was chosen from the series of IELTS tests in Cambridge IELTS 6 book and it was utilized to measure the participants' level of language proficiency. The second instrument was Discourse Complement Task (DCT). According to Varghese \& Billmyer (1996) "DCT is a questionnaire containing a set of very briefly described situations designed to elicit a particular speech act" (p. 40). The participants were asked to complete a DCT, designed by Jalilafar (2009), which took 20 minutes to answer. The validity and reliability of this questionnaire had been substantiated through a pilot study done on 10 students by Jalilafar (2009). The DCT questionnaire was administered to the participants who were asked to put themselves in each situation and respond to 20 items. In the first 10 situations, the subjects were required to use an apology strategy in order to apologize, while in the last 10 situations, the subjects were asked to use a request strategy in order to request.

\section{Procedure}

At first, the IELTS test was administered to the subjects. The participants were informed about the manner of doing the test. The participants were forbidden to use any dictionary during the test. The next step was administering the DCT questionnaire. Most of the participants were unfamiliar with this kind of questionnaire. Therefore, they were informed about the manner of doing the DCT questionnaire. The participants were asked to imagine themselves in each of the situations, not think too much, and try to answer the questions as soon as possible. Since the gender factor was important in this study, the participants were asked to determine their gender by marking their sex on the answer sheets.

Although the language in which the situations and questions in DCT were stated was English, the participants were allowed to write their answers down in Persian. The reason was that all the participants were able to read and understand the questions in English, but they were not able to transfer their own intentions and the apology and request strategies that they intended to use to answer the questions in English. Therefore, they were allowed to use their own native language, so that they did not have any limitations in answering the questions.

Later on, for the data analysis, the students' answers were translated to English and the English equivalence of the participants' answers which were in Persian were obtained. For ensuring the correctness of the translations, they were checked by some skillful translators. Then the participants' apologizing and requesting strategies were compared with Blum-Kulka \& Olshtain's CCSARP (a cross-cultural study of speech act realization patterns). CCSARP is a coding manual, designed by Blum-Kulka and Olshtain (1984), in which they identified some patterns utilized in apologizing and requesting in English contexts.

After collecting the participants' answers, the answers were compared with CCSARP to know which patterns of the CCSARP, the participants used more in order to apologize and request. The next step was inspecting the examples of CCSARP, based on one of the most comprehensive corpora, the British National Corpus (BNC). In fact, by inspecting the CCSARP patterns and examples on BNC, the researcher was able to know how many times a specific pattern has been used and which patterns have been used more than the others in order to request and apologize in English texts in various genres.

\section{RESULTS}

The hypotheses in the present study were: 
1. There is a significant difference between Iranian male and female EFL learners regarding their cross cultural speech act knowledge.

2. There is a significant relationship between Iranian EFL students' language proficiency and cross cultural speech act knowledge.

Table 1 shows the mean, standard deviation, and standard error of mean of the scores of LP variable based on gender. As it is illustrated in Table 1, the mean of the male group is more than the mean of female group.

TABLE 1

THE MEAN, STANDARD DEVIATION, AND STANDARD ERROR MEAN OF THE SCORES OF LP VARIABLE BASED ON GENDER Group Statistics

\begin{tabular}{|ll|l|l|l|l|}
\hline \multicolumn{2}{|c|}{ Gender } & N & Mean & Std. Deviation & Std. Error Mean \\
\hline \multirow{2}{*}{ dimension1 } & Male & 30 & 23.30 & 3.554 & 649 \\
& Female & 30 & 19.00 & 4.275 & .781 \\
\hline
\end{tabular}

In order to inspect the meaningfulness of this difference, considering normality of the distribution of this variable, independent t-test was utilized (Table 2). Table 2 shows that males' LP scores are higher than females' LP scores in a meaningful way $(\mathrm{t}=4.24, \mathrm{df}=58, \mathrm{P}=.000, \mathrm{P}<0.05)$.

TABLE 2

THE T-TEST FOR COMPARING INDEPENDENT GROUPS IN LP VARIABLES

Independent Samples Test

\begin{tabular}{|c|c|c|c|c|c|c|c|c|c|c|}
\hline & \multicolumn{2}{|c|}{$\begin{array}{l}\text { Levene's Test for } \\
\text { Equality of Variances }\end{array}$} & \multicolumn{7}{|c|}{ t-test for Equality of Means } \\
\hline & & \multirow[b]{2}{*}{$\mathrm{F}$} & \multirow[b]{2}{*}{ Sig. } & \multirow[b]{2}{*}{$\mathrm{t}$} & \multirow[b]{2}{*}{$\mathrm{df}$} & \multirow{2}{*}{$\begin{array}{l}\text { Sig. (2- } \\
\text { tailed) }\end{array}$} & \multirow{2}{*}{$\begin{array}{l}\text { Mean } \\
\text { Difference }\end{array}$} & \multirow{2}{*}{$\begin{array}{l}\text { Std. Error } \\
\text { Difference }\end{array}$} & \multicolumn{2}{|c|}{$\begin{array}{l}95 \% \text { Confidence Interval } \\
\text { of the Difference }\end{array}$} \\
\hline & & & & & & & & & Lower & Upper \\
\hline LP & $\begin{array}{l}\text { Equal variances } \\
\text { assumed }\end{array}$ & .470 & .496 & 4.236 & 58 & .000 & 4.300 & 1.015 & 2.268 & 6.332 \\
\hline & $\begin{array}{l}\text { Equal variances not } \\
\text { assumed }\end{array}$ & & & 4.236 & 56.128 & .000 & 4.300 & 1.015 & 2.267 & 6.333 \\
\hline
\end{tabular}

The second step was inspecting the two other variables, i.e. Apology and Requesting variables. Table 3 shows descriptive amount of apology variable. As it is revealed in Table 3, the mean score of using apology strategy in female's group is higher than male's one.

TABLE 3

DESCRIPTIVE AMOUNTS OF APOLOGY VARIABLE

Ranks

\begin{tabular}{|lll|l|l|l|}
\hline \multicolumn{2}{|c|}{ Gender } & N & Mean Rank & Sum of Ranks \\
\hline \multirow{2}{*}{ Apology } & Male & 30 & 21.13 & 634.00 \\
& \multirow{2}{*}{ dimension1 } & Female & 30 & 39.87 & 1196.00 \\
& & Total & 60 & & \\
\hline
\end{tabular}

Table 4 shows descriptive amount of Request variable. The mean score of using this strategy in female group is higher than that in male one significantly.

TABLE 4

DESCRIPTIVE AMOUNTS OF REQUESTING VARIABLE

\begin{tabular}{|c|c|c|c|c|}
\hline & Gender & $\mathrm{N}$ & Mean Rank & Sum of Ranks \\
\hline Requesting & $\begin{array}{ll} & \text { Male } \\
\mathrm{d} & \text { Female } \\
\text { Total }\end{array}$ & $\begin{array}{l}30 \\
30 \\
60\end{array}$ & $\begin{array}{l}16.38 \\
44.62\end{array}$ & $\begin{array}{l}491.50 \\
1338.50\end{array}$ \\
\hline
\end{tabular}

In Table 5, the correlation among the scores in LP variable, Apology variable, and Requesting variable has been shown. The Table 5shows that LP has a meaningful relationship both with Request strategy $(r=-.326, p<0.05)$, and with Apology strategy $(r=-.235, \mathrm{p}<0.05)$. The correlation between the scores of LP variable and the scores of Apology and Requesting variable is a negative correlation. This shows the more the students' scores in LP variable, the less their scores in Apology and Requesting variables, and vice versa. 
TABLE 5

THE RELATIONSHIP AMONG THE LP VARIABLE, APOLOGY VARIABLE, AND REQUESTING VARIABLE

\begin{tabular}{|c|c|c|c|c|}
\hline & & LP & Apology & Requesting \\
\hline \multirow[t]{3}{*}{$\mathrm{LP}$} & Pearson Correlation & 1 & -.235 & $-.326^{*}$ \\
\hline & Sig. (2-tailed) & & .070 & .011 \\
\hline & $\mathrm{N}$ & 60 & 60 & 60 \\
\hline \multirow[t]{3}{*}{ Apology } & Pearson Correlation & -.235 & 1 & $.406^{\text {क*न }}$ \\
\hline & Sig. (2-tailed) & .070 & & .001 \\
\hline & $\mathrm{N}$ & 60 & 60 & 60 \\
\hline \multirow[t]{3}{*}{ Requesting } & Pearson Correlation & $-.326^{*}$ & $.406^{* *}$ & 1 \\
\hline & Sig. (2-tailed) & .011 & .001 & \\
\hline & $\mathrm{N}$ & 60 & 60 & 60 \\
\hline
\end{tabular}

The results of this study support the first hypothesis because the results showed that there was a significant difference between Iranian EFL learners regarding their gender. On the other hand, the results reject the second hypothesis, because the study showed that there is a no significant relationship between Iranian EFL students' language proficiency and cross cultural speech act knowledge.

\section{DisCuSSION AND CONCLUSION}

One of the issues in the domain of pragmatics is the effect of gender on pragmatics acquisition. This study inspected the effect of gender on acquisition of Apology and Requesting speech acts. The results of this study showed that female participants performed significantly better than the male ones both in Apology strategy and in Requesting strategy. The findings of this study are close to Kerekes' (1996) findings. Kerekes (1996) found that female learners are more interested in using L2 norms in expression of emotions than male learners did; however, the result of this study is different from the result of the study done by Rintell (1984). Rintell (1984) found no gender differences in learner's perception of expression of emotions.

The findings of the present study are also close to Holmes' studies in (1995). Holmes (1995) investigated the differences between males and females in terms of using the frequency of complaints and apology strategy. The results suggested that there were significant differences between the performance of two gender groups regarding the distribution of apologies between men and women, and women apologized more than men did.

Lorenzo-Dus (2001) examined a corpus of over 1000 tokens of compliment responses in British English and Peninsular Spanish in terms of cross-cultural and gender differences. Like the results of this study, the study done by Lorenzo-Dus (2001) revealed gender differences in using different speech acts.

Another important issue in pragmatics domain is the effect of language proficiency (LP) on pragmatic competence (PC). Studies in this domain are rare. The present study also inspected this issue and showed that the male participants, who outperformed the female ones in language proficiency (LP) test, did not perform as well as female participants in pragmatic test. In other words, the participants with higher language proficiency (LP) knowledge were weak in pragmatic competence (PC). Therefore, the present study shows that language proficiency (LP) does not affect on pragmatic competence $(\mathrm{PC})$.

The findings of this study are in par with the findings proposed by Takahashi (1996) and Kit(2000). Takahashi(1996) found that Proficiency did not have any significant effect on pragmatic competence (PC). EFL learners with both low and high proficiency lied on some of the SL pragmatic aspects. Kit (2000) found that learners across several proficiency levels are capable of perceiving differences in situational factors. Proficiency did not have the expected effect on pragmatic competence (PC). He added that the main reason may be attributed to the fact that EFL learners just learned English through what they were exposed to in the classroom; the problem was lack of access to authentic materials. The finding of the present study is different from Barron's (2003) findings. Barron (2003) pointed out that increased grammatical proficiency may or may not cause a corresponding increase in pragmatic capabilities.

The present study showed that gender affects pragmatic competence (PC). The female participants outperformed male participants both in apology and requesting speech acts. Therefore, there is a significant difference between males and females regarding their cross cultural speech act and female participants' use of apology and requesting strategies is closer to native speakers than male participants'.

The findings of this study also showed that there is a negative correlation between students' scores in LP variable and their scores in Apology and Requesting variable. Male participants, who were weaker than female ones in pragmatic test, outperformed the female participants in language proficiency (LP) test. In other words, the participants who did not perform well in pragmatic test, performed well in language proficiency (LP) test. Therefore, the students' LP knowledge does not affect their knowledge of pragmatic competence (PC). 


\section{REFERENCES}

[1] Bardovi- Harlig, k. (2003). Evaluating the empirical evidence: Grounds for instruction in pragmatics. In K. R, Rose. \& G, Kasper (Eds.), Pragmatics in language teaching (pp. 13- 20). Cambridge: Cambridge university press.

[2] Barron, A. (2003). Acquisition in Interlanguage Pragmatics: Learning how to do Things with Words in a Study Abroad Context. Amsterdam and Philadelphia: John Benjamins press.

[3] Blum-Kulka, S., \& Olshtain, E. (1984). Requests and apologies: A cross-cultural study of speech act realization patterns CCSARP. Applied Linguistics, 5, (3), 196-213.

[4] Bublitz, W., \& Norrick, N.R. (2011). Foundations of Pragmatics. Berlin and Boston: De Gruyter Mouton press.

[5] Eslami,Z.R., \& Eslami-Rasekh, A. (2008). Enhancing the pragmatic competence of non- native english-speaking teacher candidates (NNESTCs) in an EFL context. In E. Alcón Soler \& A. Martínez-Flor (Eds.), Investigating Pragmatics in Foreign Language Learning,Teaching and Testing (pp 178-197). Great Britain: Cromwell Press.

[6] Hymes, D.H. (1972). On Communicative Competence. In J.B. Pride \& J. Holmes (Eds.), Sociolinguistics (pp 269-293). Harmondsworth: Penguin press.

[7] Jalilifar, A. (2009). Request strategies: Cross-sectional study of Iranian EFL learners and Australian native speakers. English Language Teaching, 2(1), 46-61.

[8] Kasper, G., \& Dahl, M. (1991). Research methods in interlanguage pragmatics. Studies in Second Language Acquisition, 13, (2), 215-247.

[9] Kasper, G., \& Rose, K.R. (2001). Pragmatics in Language Teaching. Cambridge: Cambridge University Press.

[10] kitis, E., Milapides, M. (1997). Read it and believe it: How metaphor constructs ideology in news discourse. Journal of Pragmatics 28 (5), 557-590.

[11] Kondo,S. (2008). Effects on pragmatic development through awareness-raising instruction: Refusals by Japanese EFL learners. In E. Alcón Soler \& A. Martínez- Flor (Eds.), Investigating Pragmatics in Foreign Language Learning, Teaching and Testing (pp153- 177). Great Britain: Cromwell Press.

[12] Lorenzo-Dus, N. (2001). Compliment responses among British and Spanish university students: A contrastive study. Journal of Pragmatics, 33 (2), 107-27.

[13] Morris, C. (1938). Foundations of the theory of signs. Chicago: Chicago University Press.

[14] O'Keeffe, A., McCarthy, M., \& Carter, R. (2007). From Corpus to Classroom: language use and language teaching. Cambridge: Cambridge University Press

[15] Olshtain, E., \& Cohen, A. (1991). Teaching speech act behavior to nonnative speakers. In M. Celce-Murcia (Ed.), Teaching English as a second or foreign language (pp. 156-165). Boston: Heinle and Heinle Publishers.

[16] Rintell, E. (1984). But how did you feel about that? The learner's perception of emotion in speech. Applied Linguistics, 5, (3), 255-264.

[17] Rühlemann, C. (2011). Corpus-based pragmatics: quantitative studies. In W, Bublitz \& N.R, Norrick (Eds), Foundations of Pragmatics (pp. 629-656). Berlin and Boston: De Gruyter Mouton press.

[18] Taavitsainen, I., \& Jucker, A.H. (2007). Speech acts in the History of English. Amsterdam: John Benjamins press.

[19] Takahashi, S. (1996). Pragmatic transferability. Studies in second language acquisition, 18, (2), 189-223.

[20] Tateyama, Y., \& Kasper, G. (2008). Talking with a classroom guest: Opportunities for learning Japanese pragmatics. In E. Alcón Soler \& A. Martínez-Flor (Eds.), Investigating Pragmatics in Foreign Language Learning, Teaching and Testing (pp. 45-71). Great Britain: Cromwell Press.

[21] Thomas, J. (1983). Cross-cultural pragmatic failure. Applied Linguistics, 4, (2), 91-112.

[22] Wolfson, N. (1981). Compliments in Cross-Cultural Perspective. TESOL Quarterly, 15, (2), 117- 24.

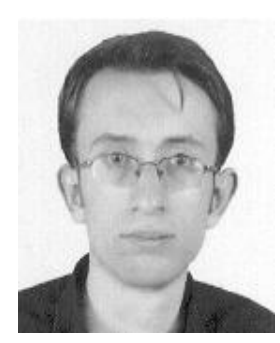

Javad Bijari is an MA student in TEFL at Islamic Azad University, Science and Research Branch, Hamadan, Iran. His main domain of interest includes second language acquisition and interlanguage Pragmatics.

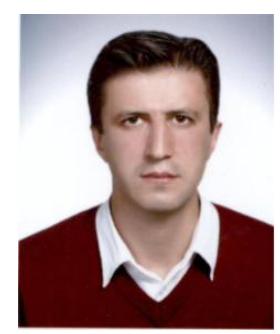

Ali Gholami Mehrdad is a lecturer in the Department of English at Islamic Azad University, Hamedan Branch, Iran. He has compiled a two-volume course for pre-requisite and general English classes, has done research on EFL students' learning styles and strategies as well as EFL writing , has translated books and has published more than 10 articles in leading ESL/EFL journals. His research interests include ESP, EFL writing instruction, learner variables, collaborative language practice, task-based language instruction, and dynamic assessment. 


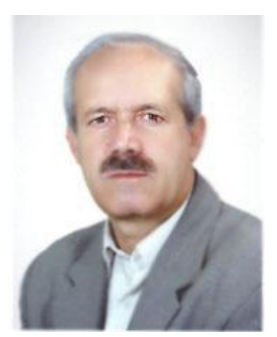

Lotfollah Karimi was born in 1962 in Sanandaj, Iran. He completed his Bachelor Degree in TEFL in Tabriz University, Tabriz, Iran, further finished his Master Degree of TEFL in Islamic Azad University, Tehran, Iran and got his PHD in TEFL in Islamic Azad University, Esfahan, Iran. He is faculty member of Islamic Azad University of Hamadan, Iran and has been teaching courses in TEFL in B.A. and M.A. levels since 1990 up to now there. His main areas of interest are research and applied linguistics. He has published several books like Fundamentals and Principles of Translation Theory and An Introduction to Morphology and articles in the field of TEFL and testing in different international journal such as World Applied Sciences Journal and Journal of Higher Education Studies. 